\title{
CSELIK ÁGNES:
}

\section{ESTRUCTURA NARRATIVA DE LA NOVELA “LA CIUDAD AUSENTE” DE RICARDO PIGLIA}

En la novela titulada La ciudad ausente de Ricardo Piglia se trenzan por lo menos tres historias: en primer lugar, la de Junior, un periodista que, a la vez que investiga la aparición en la ciudad de una serie de grabaciones producidas por una máquina ubicada en un museo, va descubriendo su identidad; en segundo lugar, la del origen de la propia máquina, invento ideado por Macedonio Fernández y llevado a cabo por un ingeniero, Emil Russo; en tercer lugar, la historia política argentina durante la dictadura militar, justo después de la guerra de las Malvinas.

La estructura narrativa mezcla estos tres relatos, imbricados con una serie de otros microrrelatos, formando un mosaico donde se alternan yuxtapuestos distintos tiempos y espacios narrativos.

Dado que la novela es una red muy complicada de historias entretejidas, tanto los críticos como el mismo autor, intentaron resumirla y explicarla varias veces:

“J. A. M.: La novela sugiere un complot para anular a una máquina-mujer, capaz de pergeñar relatos que revelarían algo; y hay un museo donde cada uno puede hallar símbolos de su propia historia; y se incluyen varios minicuentos, casi en estado de esbozo. Y están allí la represión y la política, y Macedonio Fernández y su Museo de la Novela Eterna.

R. P.: Básicamente, es la historia de un hombre que no soporta la pérdida de su mujer; ese hombre es Macedonio Fernández, quien hace un pacto fáustico con un inventor: éste crea para él una máquina, asegurándole que allí su mujer permanecerá viva. (...)

J. A. M.: Para volver a La ciudad ausente: ¿No hay en ella también una relación con cierta tradición argentina, como la novela El examen de Cortázar, con esa ciudad que se va desintegrando, o Megafón de Leopoldo Marechal y su combate centrado en el rescate de una mujer que es además un símbolo?

R. P.: Por otro lado está la conexión con Macedonio Fernández, en la idea del Museo y de la Novela Eterna; y es, claro, hay una relación con el modelo macedoniano de que la realidad no puede ser contada con los registros de la literatura realista. (...) el enamorado es un egoísta que no se da cuenta de que va a morir, y la mujer va a quedar eternamente prisionera. Para poder escribir el libro yo trabajé con la idea paralela de que podía tratarse de una psicótica internada en una clínica y que cree que es una máquina de contar, y después está la otra historia, la realidad en la cual esa máquina se inserta y que es también una realidad producida por ella. Y aquí le voy a decir algo: yo pienso que el narrador investigador, Junior, es también un personaje de la máquina; me parece que ella construyó ese personaje que viene a salvarla."1

Como se ve de la complicidad de todo tipo de resumen, estamos ante una novela que ya desde el principio nos brinda historias e ideas paralelas.

En el fondo del mensaje de la novela está la política, que a la vez es la que más llama la atención. Se trata de la situación política concreta de la Argentina en el transcurso de la guerra de las Malvinas, y después, durante la época de la dictadura militar:

“Ciertos comentarios y cierta versión de los hechos le hicieron recordar los días de la guerra de las Malvinas. Los militantes argentinos habían perdido la guerra y nadie lo sabía. Las mujeres tejían abrigos para los conscriptos en tiendas improvisadas en la plazoleta del obelisco.” (p. 88)

El Estado niega los verdaderos acontecimientos, evita la circulación de las informaciones para poder manipular a los ciudadanos. El poder totalitario necesita gente obediente e ignorante, castiga, controla y amenaza a todos los que quieren saber lo que ocurre en realidad.

"La política siempre ocupa el lugar del destino (...) Otra vez la figura de la amenaza que se planifica desde un centro oculto (en este caso ’la inteligencia del Estado') y se impone a la realidad.”2

\footnotetext{
1 Madrazo, Jorge Ariel: Entrevista a Ricardo Piglia Atanea. Ciencia, arte y literatura. Número 473, Año 1996, Universidad de Concepción de Chile. Primer semestre. pp. 96-104

2 Piglia, Ricardo: Un trama de relatos In. Crítica y ficción, Siglo Veinte. Entrevistas. Universidad Nacional del Litoral, Buenos Aires, 1990, p. 62
} 
La amenaza y la persecución, el hacer callar a los que podrían contradecir, son fenómenos comunes a todas las dictaduras de todos los tiempos. La misma lógica de función tienen las dictaduras de Europa: la dictadura de los nazis y la de los comunistas. Un momento crucial, simbólico, es 1956 en Hungría, cuando resultó que los que habían depositado su fe en los comunistas para poder luchar contra los nazis, después de la llegada del Ejército Rojo a Hungría, se vieron otra vez perseguidos y amenazados. El poder totalitario comunista exigió el control absoluto y sofocó todo tipo de rebelión. En momentos históricos, cuando se enfrentan dos poderes totalitarios, el individuo tiene que elegir entre ellos por obligación, pero no puede haber elección buena. El poder totalitario siempre tiene los mismos enemigos, sea cual fuere su ideología. El espíritu libre y el carácter que no está dispuesto a la sumisión total siempre son peligrosos para la dictadura. Lazlo Malamüd y Russo emigraron de Hungría en 1956. Como muchos otros emigrantes de Europa del Este, salieron de su patria para verse perseguidos y amenazados también en Argentina. De este modo los acontecimientos de Argentina son las réplicas de los acontecimientos europeos, o al revés, los europeos son las réplicas de los de Argentina. De todas formas la represión y la persecución son las mismas. La novela La ciudad ausente habla de todos los poderes totalitarios del mundo.

La dictadura crea un mundo basado en las mentiras y en el miedo. Crea instituciones de represión: la cárcel, la clínica psiquiátrica; tiene su Servicio de Inteligencia, controla, vigila continuamente a sus propios ciudadanos. Perfecciona las armas sin cesar, teniendo que hacer pruebas de vez en cuando para ver el resultado conseguido (Hiroshima, p. 150.). Macedonio delira ante la guerra eterna:

"La guerra finaliza y sólo quedaremos ante la inmensidad de los oscuros planes de EE.UU., que quiere herir y anular a España para hacer más fácil presa de la América hispana. Las islas han sido ocupadas, el laboratorio debe ser preservado.” (p. 60)

El modelo del estado totalitario es el japonés, el del ciudadano obediente, dispuesto a cumplir todas las ordenes recibidas sin plantear la menor pregunta. El Estado narra, éste es el medio por el que se hace "legítimo".

“...el Estado narra. Cuando se ejerce el poder político se está siempre imponiendo una manera de contar la realidad.”3

"El Estado narra [los mitos que propaga sobre la Nación]. Ésa es una función imprescindible para ejercer la dominación."4

"El Estado es también una máquina de hacer creer."

Frente a la narración del Estado se encuentra la narración de la resistencia:

"Podríamos decir que hay siempre una versión de los vencidos. Un relato fragmentado, casi anónimo, que resiste y construye interpretaciones alternativas y alegorías.” 6

Macedonio y Russo crearon una máquina de defensa femenina que narra continuamente la versión de los vencidos, narra sobre lo que está prohibido y perseguido hablar, revela los secretos del Estado totalitario, cuenta lo que el Estado prefiere ignorar para no tener que hablar de ello, y habla de la muerte, de la desesperación, del dolor, de la soledad. La máquina es, o era, una mujer por definición. En todas las mitologías el origen de la vida está estrechamente vinculada con el principio femenino, con la maternidad. Frente a las mentiras del Estado, la máquina crea literatura femenina, es decir, crea literatura oral, que circula en varias versiones y con diferentes vías de distribución por toda la Argentina.

La máquina es el río eterno de los relatos, se le puede llamar con mil nombres, se identifica con todas las mujeres de la narración, pero principalmente es Eva, es Anna Livia Plurabelle y es Elena, la Eterna. El destino de todas las mujeres es ser perseguidas, torturadas, amenazadas y encerradas, y que no por ello dejen de seguir la narración. Su tema es autorreflexivo, por lo tanto la máquina habla del poder totalitario, de las mujeres y hombres torturados, de la vigilancia, de la pérdida del hombre amado, de la muerte. La muerte del ser querido es inevitable, en parte debido a los asesinatos cometidos por el Estado, y en parte como consecuencia de la debilidad física, de la enfermedad. Lo trágico es que no hay reconciliación alguna entre la vida y la muerte. La muerte se presenta como un fenómeno imposible de aceptar, que hiere "mortalmente" tanto al muerto como al

\footnotetext{
3 Op. Cit.: p. 61

4 Piglia, Ricardo: Locos, bandidos y fundamentalistas Clarín, 9-V-1993

5 Piglia, Ricardo: Los relatos sociales In. Crítica y ficción Siglo Veinte. Entrevistas. Universidad Nacional del Litoral, Buenos Aires, 1990, p. 180

6 Piglia, Ricardo: Un trama de relatos In. Crítica y ficción Siglo Veinte. Entrevistas. Universidad Nacional del Litoral, Buenos Aires, 1990, p. 63
} 
que sobrevive. El/la amante vivo/a siempre se siente abandonado/a. La máquina, el principio femenino narra del hombre que le abandonó, y el hombre narra de la mujer que le dejó solo. Hombre y mujer forman parte de la misma totalidad, la mujer es la parte inversa/complementaria del hombre y el hombre es la parte inversa/complementaria de la mujer. Tanto la voz femenina como la masculina hablan de las mismas experiencias, de la misma pérdida, de la misma soledad. Todas las voces narradoras llegan a formar una melodía polifónica de la narración.

La narración es eterna, no tiene ni tiempo ni espacio concreto, como suele ocurrir con las actividades míticas. Para José Arcadio Buendía siempre es lunes en Cien años de soledad. En esta novela todo ocurre en dos horas, dos días, dos meses y dos años. La diferencia entre hora-día-mes-año es insignificante comparada con la eternidad de la narración.

Junior llega a saber las noticias dos horas antes de que el acontecimiento haya ocurrido (p. 10), después de visitar el Museo pasa dos noches sin dormir (p. 87), y pasa dos noches metido en su cuarto (p. 97) después del encuentro con Julia Gandini [que estuvo dos meses internada en la clínica (p. 85)]. Junior pide ayuda a Ana Lidia resaltando que hace dos meses que está metido en esta historia (p. 106). En la isla, la lengua que más tiempo permaneció se mantuvo quieta durante dos años (p. 120) y Boas dice que hace dos meses que salió de la isla (p. 134). Él lleva contando la historia de la isla desde hace dos meses, y Junior, desde hace dos meses, está investigando las historias que circulan por la ciudad. Cuando Junior se acerca a la isla de Russo la vegetación cambia a las dos horas de salir, y Junior tiene la sensación de cruzar una frontera (p. 137.). Russo le dice a Junior que los materiales de investigación le llegaron a los $\underline{\text { dos }}$ meses de la librería.

El dos es un número par, porque en esta novela todo tiene su paralelismo, su réplica, su opuesto o su inversión. El dos es un número que se encuentra en ambos lados del espejo, reflejándo su imagen inversa: Es la unidad hecha fracción y al mismo tiempo, según su significado numeral esotérico, es el reflejo pasivo de la Unidad. Además es considerado como la fuente de los errores mentales. Hemos visto en la novela que todos los personajes están o pueden estar 'locos', y cada narración puede ser interpretada como fruto de algún tipo de delirio. El número dos tiene importancia en cada escala de la narración, es decir, en cada fractal.

Las referencias temporales anteriormente mencionadas se combinan con una hora mítica que son las tres de la tarde.

Cuando Junior sale del Museo, en el reloj del mismo eran las tres de la tarde (p. 65), la narración Stephen Stevensen revela que el doble de Stephen Stevensen llegó a las tres de la tarde (p. 98), y eran las tres de la tarde cuando Junior visitó a Ana Lidia.

El tres es un número impar, primo, y en la astrología es el símbolo del eje central entre la Tierra, la Luna y el Sol. Según su sentido numeral esotérico, el tres es la inteligencia infinita, por lo tanto es la antítesis del número dos, que simboliza los errores mentales. Además de ser el tres la antítesis del dos, es la unidad repetida tres veces, el dos más uno.

El tiempo definido por la presencia de los números dos y tres, descrito con la repetición constante de estos elementos, es fijo, eterno, no tiene intervalo ni duración verdadera.

El espacio parece más fragmentado.

En la ciudad las calles están vacías, las patrullas controlan, aunque sea inútil, y la vida se queda relegada a los pasos subterráneos de la Avenida 9 de Julio, aunque al final de la novela estos locales están abandonados también (p.168). El Museo está cercado, vigilado, prisionero en este control absoluto, y en las clínicas psiquiátricas torturan a los internados para conseguir más información. La gente -Macedonio, Junior, etc.- vive en alojamientos transitorios, en piezas de hotel. No hay hogares que puedan ser escenarios de la vida familiar pacífica y equilibrada, y los lugares de trabajo que aparecen, siempre son variantes de una prisión. Fuyita trabaja en el Museo, es el personal de control que vigila la máquina, y es vigilado, controlado a la vez por el sistema de seguridad y por la máquina. Junior trabaja en la redacción de El Mundo (tampoco hay que olvidar que el nombre del diario es simbólico), donde todos son prisioneros, él también (p. 10.). La ciudad es un sitio peligroso, de donde hay que huir, salir, encontrar alguna escapatoria, porque es la única forma de intentar sobrevivir.

El campo, la pampa es la llanura deshabitada, siempre estamos en el borde de la nada, y siempre hay algunas vías del Ferrocarril Central Argentino. El campo tiene algunos lugares céntricos, donde tarde o temprano acuden todos los personajes de la novela. Se trata de dos (!) ciudades: Azul y Bolívar. Son ciudades vecinas, réplicas una de la otra, totalmente idénticas en su carácter. EI gaucho invisible llega a ser visible para sus compañeros en el pueblo de Azul; los padres de La nena viven en Bolívar. Russo se establece en Bolívar y los que vienen a practicar el tiro al blanco son los conscriptos de Azul. Junior confiesa ser procedente de Bolívar, y es aquí donde se encuentra la casa a donde regresó Macedonio después de recorrer toda la provincia de Buenos Aires. En el campo encontramos la réplica del Museo de la ciudad, los dos museos se contemplan como los pueblos de Azul y Bolívar. En el campo la tierra está llena de pozos, que son tumbas, de miles de indios asesinados, y de hombres y mujeres atados, desnudos, matados a tiros, mientras sonaba música en los altavoces de las furgonetas. En el campo tampoco hay hogares para vivir.

La isla es un sitio mítico, es el refugio de los muertos, es donde se hace palpable que nadie está en casa, nadie habla su lengua-madre, todos son inmigrantes y perseguidos. 
El espacio donde ocurren los acontecimientos de la novela tampoco es concreto, se trata de lugares más bien abstractos, equivalentes a "cualquier lugar".

En la novela titulada La ciudad ausente la ausencia es una realidad material. Es incuestionable que no se trata de una ciudad concreta, ni tampoco se trata de la ciudad como unidad arquitectónica. Carolina Ferrer lo explica de esta manera:

"En términos contemporáneos, la ciudad es un símbolo de la madre, en su doble aspecto de protección y de límite. Cabe destacar que las madres mencionadas en la novela -la madre de Junior, al igual que su mujer y la mujer de McKinley- se han ido, dejando a los hombres solos. Así mismo, la muerte de Elena ha impulsado a Macedonio a buscar a Russo para crear la máquina. Esta última tampoco tiene madre: en términos materiales, fue creada por Russo y Macedonio, y por Nolan en su orígen mítico. En este sentido la ausencia de imagen materna opera a distintos niveles: personajes, máquina, ciudad. Por lo tanto, se puede hablar de fractales, ya que ante cambios de escala, se sigue observando un fenómeno casi idéntico: la ausencia materna.”7

La explicación brindada por Carolina Ferrer es indudablemente válida sin embargo, creo que no llega al fondo. La ciudad es más que un simple símbolo de la madre, la ciudad es el sitio donde los hombres conviven, donde se crean relaciones interpersonales. En la esperanza escatológica la Jerusalén Celestial es el escenario de la convivencia perfecta, donde se crea la unidad, la verdadera comunidad de los habitantes. Y justamente son estos los fenómenos que no aparecen en la novela, que están ausentes.

No hay relaciones interpersonales: no hay amistad, la "amistad" del doctor Ríos a Russo le costó la vida.

Tampoco hay amor: hombres y mujeres son incapaces de acercarse, de salir de su aislamiento (Junior-la mujer en el Majestic, Julia Gandini, Ana Lidia, etc.) o si nace el amor, obligatoriamente tiene que romperse por la desaparición del hombre o de la mujer, por la ausencia del ser querido: (Primer amor, Junior-su esposa, Macedonio-Elena, Russo-Carola Lugo, Nolan-la máquina).

No existe la familia, la madre abandona a su marido y a sus hijos (la madre y la esposa de Junior, Una mujer), y el padre cuando se queda solo prefiere alejarse de los hijos (Macedonio).

Claro que no hay relaciones interpersonales, si no hay personalidades tampoco. El lector no llega a conocer a los personajes de la novela, porque no tienen características propias, o si las tienen, carecen de importancia: Una mujer, La nena.

En otros casos es la función la que predomina sobre el hombre: el ingeniero, el escritor, el periodistadetective, etc.

Ya hemos visto que todas las mujeres son réplicas de la máquina, de esta manera la máquina tiene una serie de nombres propios que designan al mismo sujeto: Elena, Ana Lidia, Julia Gandini, Lucía Joyce, Anna Livia Plurabelle, Belle Blue Boylan, etc. Los nombres propios pierden la cualidad de hacer una distinción entre las personas, puesto que todos los nombres femeninos tienen un denominado común.

El caso de los nombres masculinos es parecido a los femeninos. Algunas funciones disponen de dos (!) nombres propios: el ingeniero Richter y Russo; el periodista Emilio Renzi y Junior.

Llama la atención que muchos nombres masculinos son variantes de Macedonio, empiezan por Mac: Mac, el que trabaja en el taller clandestino en Los nudos blancos; Mac Kensey, el padre de Junior; McKinley, jefe de estación del Ferrocarril Central Argentino, réplica del padre de Junior; y el mismo Junior, que se llama Miguel Mac Kensey, igual que su padre.

Dos (!) de los personajes son tocayos y, además, poseen las mismas iniciales: E.R. Emilio Renzi, que aparece como narrador al comienzo de la novela y a su vez, el ingeniero Emil Russo.

Macedonio y Russo construyen la máquina, de este modo se unen en la misma función y se identifican con Nolan, el creador mítico de la máquina en $\mathbf{L} \boldsymbol{a}$ isla.

Todos los hombres son narradores, su narración puede ser directa o a través de la máquina. Todos son solitarios, abandonados, y hablan de los mismos temas: de la opresión, de la persecución, de la resistencia, de la máquina, de la mujer perdida. Las narraciones masculinas son autorreflexivas, igual que las de la máquina, y al comparar los temas de narración masculina y femenina podemos sacar la conclusión de que se trata de la misma melodía polifónica de la narración que cuenta paralelamente la versión femenina y masculina de la misma historia.

Los nombres utilizados por Ricardo Piglia, que además de aludir a todos los personajes de la novela aluden a escritores (Macedonio Fernández, Leopoldo Lugones, Emile Rousseau) y a otros personajes de otras obras de Ricardo Piglia (Lucía Joyce-Lucía Nietzsche en El fluir de la vida; Emilio Renzi es el narrador de varias obras de Ricardo Piglia y es una clara alusión a sí mismo), son fruto de una elección cautelosa. Como lo explica Emili Renzi en Respiración artificial:

\footnotetext{
${ }^{7}$ Ferrer, Carolina: Una compleja máquina de narrar: La ciudad ausente de Ricardo Piglia www.uchile.cl/facultades/filosofia...caciones/cyber/Cyber3/textos/CFERRER.HTML, p.7 
“Ahora bien, dijo Renzi, el policía a quien el protagonista del cuento de Borges [El indigno] va a ver para delatar a su amigo se llama, en el relato de Borges, Alt. Sabés mejor que yo, sin duda, el significado que tienen los nombres en los textos de Borges, de modo que nadie me hará creer que ese apellido, con esa R que falta, letra inicial, diría yo, de otro nombre, con esa R justamente que falta, está puesto ahí por azar.”8

Tenemos que afirmar que los nombres parecen tener un valor simbólico muy importante, mientras no hay personalidades en la novela que podrían designar. Todos los personajes (femeninos y masculinos) pierden la identidad y se unen en la escritura. A consecuencia de ello los nombres propios que aparecen también serán desprovistos de las características personales y serán variantes del mismo denominado abstracto.

Las voces narradoras sostienen un monólogo infinito, monólogo que nunca llega a ser diálogo, medio de la relación interpersonal. Desapareció la personalidad propia. En la novela domina la alucinación, el delirio, y el estado equizofrénico que también tiene sus huellas en el lenguaje utilizado. La nena tiene un "desarrollo" lingüístico contrario a lo normal, primero deja de utilizar las conexiones gramaticales, omite los pronombres personales, y poco a poco prescinde de las palabras, primero sustituyéndolas por una definición genérica (en vez de manteca prefiere decir "barro suave"), y al final la melodía de la lengua se reduce a un cloqueo monótono. Según la teoría de Iván Fónagy la melodía precede a la articulación de la frase; en el caso de $\boldsymbol{L a}$ nena vemos que sólo la melodía persiste después de la desaparición de la articulación de la frase.

La máquina de Nolan mezcla las lenguas, Macedonio después de la muerte de Elena evita las palabras que le traen a la memoria el dolor, y en $\mathbf{L} \boldsymbol{a}$ isla hay un cambio continuo de lenguas, cuya vigencia pierden a la hora del cambio del idioma. Sólo persiste la melodía, como en el caso de La nena, pero los que quieren cantar ya no se acuerdan de la letra.

En la lengua vemos el mismo proceso de enajenamiento que en el caso de las personas. La lengua llega a ser despersonalizada, abstracta, no es la lengua-madre, es ajena a todos, es difícil o imposible entenderla, sobre todo porque todo el mundo habla en clave. (En este registro también podríamos hablar de la ausencia de la madre.) Se perdió la conexión inmediata entre la enunciacón y el enunciado, se rompió la unidad orgánica, la armonía primitiva.

La humanidad rompió los nudos blancos, los nudos de condensación y de la memoria y ahora está perdida en la selva de las informaciones. Hay tantos datos, tantas teorías y tantas posibilidades almacenadas en el cerebro humano, que a falta de unos principios calificadores, pierden el significado y la validez. La novela está llena de alusiones científicas, de citas de personajes importantes de la teoría lingüística, literaria, histórica y de la teoría de las ciencias naturales. De forma directa o indirecta la novela incluye la tradición literaria de todos los tiempos también. El texto es un palimpsesto, porque no hay nada que sea absolutamente original. La vida tampoco puede ser original, está determinada por las características heredadas, inscritas en el ADN, que, con su forma de espiral doble, es la réplica de los círculos y espirales que determinan la estructura de la presente novela.

Además de que la novela incluye la tradición literaria de siempre, en la misma obra circulan copias que curiosamente están relacionadas con Avellaneda, ciudad industrial (considerada un gran suburbio) en las cercanías de Buenos Aires, por lo tanto bien puede ser que en Avellaneda haya imprentas. Sin embargo no deja de ser simbólico que este nombre sea el apellido del que en 1614 editó el llamado "Falso Quijote", una continuación de la primera parte del Quijote y una falsificación proléptica de la segunda parte escrita por Cervantes, conocido en la historia de la literatura como Alonso Fernández de Avellaneda.

"Las hacen en Avellaneda, en talleres clandestinos de la provincia.” (p. 17)

“Alguien está vendiendo copias falsas en un taller de Avellaneda.” (p. 105)

A Julia Gandini la llevan al neuropsiquiátrico de Avellaneda, y por último, en la contraportada de La ciudad ausente leemos:

"Esta edición se terminó de imprimir enVerlago S. A. Producciones Gráficas Spurr 653, Avellaneda, en el mes de septiembre de 1995”.

La novela misma no es otra cosa que una copia (probablemente una copia falsa de una versión original), del lenguaje común de todos los seres vivos, cuyo mapa descubrimos en el caparazón de las tortugas. Las obras de arte son variantes de un todo, y cada obra es un todo en sí mismo también. Todas las narraciones incluidas en la novela son réplicas una de la otra, y son circulares, girando alrededor de la exaltación de la ausencia.

Hay que redescubrir la unidad primitiva, empezar todo de nuevo, dejar la dirección errónea y comenzar otra, nueva. La manera del redescubrimiento de los nudos blancos, de encontrar el camino según las indicaciones del mapa dibujado en el caparazón de las tortugas, es a través de las narraciones. A la pregunta planteada, pero no

8 Piglia, Ricardo: Respiración artificial. Primera edición: Pomaire, Buenos Aires,1980, Edición consultada: Seix Barral/Biblioteca Breve, Buenos Aires, 1996, p. 173 En la cita Emilio Renzi alude al escritor argentino, Roberto Arlt. 
pronunciada, la narración responde con otro enigma: refleja la réplica de la pregunta, da una imagen inversa de la vida, incluso ofrece la réplica de la narración misma.

“R. P.: La experiencia, vamos a decir, es 'el modo en que un sujeto conoce la realidad'. Bueno, 'experiencia' es igual a la 'narración'.”9

"Se vive para escribir, diría yo. La escritura es una de las experiencias más intensas que conozco. La más intensa, pienso a veces. Es una experiencia con la pasión y por lo tanto tiene la misma estructura de la vida."10

"La escritura es el lugar donde los borradores de la vida son posibles, tal vez por eso se hace literatura. Ahora eso al mismo tiempo es ridículo. Es ser un clown, porque supone algo tan irrisorio como pretender que se puede reconstruir una especie del laboratorio y con palabras la experiencia. Y es ridículo pero tiene, sin embargo, una carga de pasión que hace que escribir sea una de la experiencias más intensas de la vida.»11

Narrar y vivir tienen el mismo estatus ontológico, por lo tanto todas las narraciones son réplicas en miniatura del orden del mundo, y las categorías de la realidad y de la ficción se entrelazan. De esta manera se produce el efecto prisma, los diferentes registros de la existencia se ven reflejados uno al lado del otro, totalmente iguales en derecho, sin la superposición y la subordinación a las que estamos acostumbrados. En este mundo la lógica causal deja de funcionar.

El individuo sale a la búsqueda de alguna certeza, busca el camino que tiene que recorrer. Otra vez prestamos las palabras de Northrop Frye:

"La mayoría de los viajes literarios son una búsqueda de alguna forma. El héroe sale de su casa para cumplir el ejercicio de la búsqueda, y al final regresa a casa. La base de la búsqueda entonces es algún tipo de movimiento cíclico o laberíntico, y la mayoría de las veces el desenlace final no es una simple llegada a casa, tampoco lo es en Ulises, a pesar de que aparenta serlo. Gracias a la visión del desenlace final de la narración, el círculo horizontal llega a tener una dimensión vertical, del tipo de espiral. La espiral entre otras cosas es un laberinto estilizado, y el movimiento sinuoso o laberíntico, se transforma en un movimiento lineal y dirigido, cuya meta es la liberación del laberinto, este movimiento es el tema eterno de la literatura.”12

El que busca, investiga, desempeña el papel del detective, cuyo representante en la novela es Junior.

“El relato policial narra la aventura del hombre en busca de la verdad oculta.”13

De esta forma todas las narraciones son policiales, porque contienen alguna verdad oculta, igual que el Museo de la Novela Eterna se identifica con el Museo Policial, dedicado al arte de la vigilancia. Todos los personajes, todos los lectores y críticos son detectives que buscan el secreto.

"Un crítico literario es siempre, de algún modo, un detective: persigue la superficie de los textos, las huellas, los rastros que permiten descifrar su enigma. A la vez, esta asimilación (en su caso un poco paranoica) de la crítica con la persecución policial, está presente con toda nitidez en Arlt. Por un lado Arlt identifica siempre la escritura con el crimen, la estafa, la fasificación, el robo. En este esquema, el crítico aparece como el policía que puede descubrir la verdad. Escritura clandestina y culpable, escritura fuera de ley, se entiende que Arlt haya buscado que sus libros circularan en un espacio propio, fuera de todo control legal."14

\footnotetext{
${ }^{9}$ Viereck, Roberto: De la tradición a las formas de la experiencia:Entrevista a Ricardo Piglia, Revista-Chilena-de-Literatura, Santiago, Chile (RChL). 1992 Nov, 40, p. 135

10 Piglia, Ricardo: La lectura de la ficción, In. Crítica y ficción Siglo Veinte. Entrevistas. Universidad Nacional del Litoral, Buenos Aires, 1990, p. 24

${ }^{11}$ Piglia, Ricardo: La literatura y la vida, In. Crítica y ficción Siglo Veinte. Entrevistas. Universidad Nacional del Litoral, Buenos Aires, 1990, p. 188

${ }^{12}$ Frye, Northrop: Az Ige hatalma Európa Könyvkiadó, Budapest, 1997 (Ford.: Pásztor Péter) „A legtöbb irodalmi utazás valamilyen formában keresés. A hős elutazik otthonról, hogy teljesítse a keresés feladatát, majd végül hazatér. A keresés alapja tehát valamiféle ciklikus vagy labirintusszerü mozgás, a legtöbb vége azonban nem egyszerü hazatérés, még az Odüsszeiában sem, pedig ott nagyon is annak látszik. A vízszintes kör az irányított mozgásnak, az elbeszélés vége látomásának spirális, függőleges dimenzójára tesz szert. A spirál egyebek mellett stilizált labirintus, és a labitintusból való szabadulás, melynek során a tekervényes vagy útveszejtő mozgás kiegyenesedik, és irányítottá válik, örök témája az irodalomnak.”, p.130

13 Chandler, Raymond: Apuntes sobre la novela policial, In. Cartas y escritos inéditos Buenos Aires, Editorial La Flor, 1976

${ }^{14}$ Piglia, Ricardo: Homenaje a Robert Arlt, In.: Nombre falso, Siglo Veintiuno Editores, Argentina S.A., Buenos Aires, 1975 (p. 135)
} 
"Por fin: cuando uno se dice -como Arlt- que todo crítico es un escritor fracasado ¿̇no se confirma de hecho un mito clásico de la novela policial? El detective es siempre un criminal frustrado (o un criminal en potencia). No es casual que Freud haya escrito:

'La historia de un texto se asemeja a un asesinato: lo difícil no es cometer el crimen, sino ocultar las huellas.'

En más de un sentido, el crítico también es un criminal."15

Todo crítico literario (y lector), por un lado es un detective, y por el otro es un escritor fracasado. El escritor/narrador es un criminal, porque todo texto literario se identifica con un crimen. El lector va en busca de la verdad oculta; el escritor, con una mano intenta borrar las huellas, pero con la otra mano deja rastros deliberadamente. Entre los rastros hay también algunas pistas falsas, pero al fin y al cabo el escritor quiere ser descubierto, entendido. Visto de este modo, el escitor es un criminal frustrado.

La búsqueda cíclica, laberíntica, del tipo espiral, es eterna, porque el secreto es imposible de formular, está escondido entre los tejidos del texto y está compuesto tanto de las palabras como del silencio:

"Hay ciertos secretos que no se dejan expresar, hay misterios que no permiten que se los revele. Y así, la esencia de todo crimen queda inexpresada."16

Con el desenlace final de la novela, la búsqueda no se ha terminado. La última acción en la novela La ciudad ausente es que el narrador se arrastra al borde del agua para cruzar el río, salir en busca de Grete Müller, que a su vez está buscando al narrador. La novela se termina y sugiere que, a la vez que se empieza otra búsqueda, se empieza otro movimiento cíclico en la gran espiral de la existencia.

Posiblemente ni siquiera es la máquina la que cuenta, sino los que se ven reflejados en ella. La máquina es una denominación metonímica para lo que es "pura energía" (p. 106); y funciona como un espejo que siempre da la imagen inversa de la que está delante de él. La máquina refleja la ausencia, por lo tanto provoca la narración que habla de una serie de ausencias: del ser querido, de la pesonalidad, de la lengua, del tiempo, del espacio, de la felicidad y de la libertad.

La ciudad ausente es una novela que no respeta ningún registro tradicional. Las categorías de tiempo, espacio, la lengua y la personalidad dejan de funcionar en el universo de la obra, y a la vez desaparece la vigencia de la lógica causal. Al lector, acostumbrado a pensar de acuerdo con los registros negados, le resulta imposible "leer" la novela según la estrategia tradicional de la lectura. El texto llega a ser simplemente "ilegible" si no hacemos una profundización en el fondo de la estructura narrativa. Como consecuencia el lector se ve desprovisto de la libertad de 'elegir' entre las interpretaciones posibles. A lo largo de la novela se repiten las mismas incertidumbres y las mismas dudas. En el primer capítulo se plantea la pregunta acerca de la identidad de Junior (si es un agente del Estado o no), y en el último capítulo se vuelve a plantear la misma pregunta. La novela pregunta, pero no ofrece respuestas claras.

Una de las interpretaciones más tradicionales y más practicadas de $\mathbf{L a}$ ciudad ausente es la política. Sin embargo, según mi parecer, la novela tacha, en el sentido derridiano de la palabra, la posibilidad de la lectura política. Cada Estado tiene su determinada estructura, y la novela presente niega la estructura, por lo tanto niega el Estado, declara nula la realidad política. Frente al poder anónimo se encuentran actantes abstractos, que no llegan a ser personalidades o caracteres independientes, y los narradores tampoco tienen actividades reales fuera del hecho de narrar.

Según el concepto de desconstrucción de Jacques Derrida ${ }^{17}$ en el origen no hay palabra, sólo hay escritura. Las narraciones en la novela titulada La ciudad ausente circulan en forma grabada o escrita. Prácticamente no existe un idioma común, los personajes nunca llegan a entenderse, no se puede formar una relación interpersonal, tampoco un diálogo bilateral. Con el cambio de la lengua a la escritura "we put the languague under erasure"18, es decir, la tachamos, la borramos definitivamente.

Sin embargo, en la novela de Ricardo Piglia, después de volver la lengua extremadamente abstracta e inadecuada para la comunicación verbal, persiste la melodía. La solución según Derrida equivaldría a la negación total de la persistencia de la palabra. En este sentido hay una enorme diferencia entre el punto de vista europeo y el latinoamericano. Ricardo Piglia, siendo un autor latinoamericano, elige otro camino frente a la negación total. La melodía persiste, por lo tanto hay algo primordial, existe una unidad primitiva que permanece vigente, y en base a esto se puede intentar reconstruir alguna comunicación arraigada en la lengua.

\footnotetext{
15 Op. Cit. (p. 136)

${ }^{16}$ Cortázar, Julio: Prólogo a los cuentos de E. A. Poe, In. Poe, -Edgar Allan: Cuentos 1-2, Prólogo, traducción y notas de Julio Cortázar, Alianza Editorial, S. A., Madrid, 1998

${ }^{17}$ Culler, Jonathan: Dekonstrukció (ford.:Módos Magdolna), Osiris Kiadó, Budapest, 1997

${ }^{18}$ Harvey, Irene E.: Derrida and the Economy of Difference Studies in phenomenology and existential philosophy, Bloomington, Indiana University, Pr., cop. 1986
} 
La resistencia al control absoluto subyace en la complejidad de la obra. El poder político es incapaz de descifrar la novela, de penetrar en la estructura narrativa, y por lo tanto le resulta imposible cambiar su código narratológico. El texto está escrito en clave y esto no es otra cosa que lo abstracto llevado a su extremo. 


\section{BIBLIOGRAFÍA CONSULTADA}

- Avelar, Idelber: Bares desiertos y calles sin nombres: Literatura y experiencia en tiempos sombríos, Revista Cultural de Crítica 1994 Nov, 9 37-43

- Ariel-Madrazo, Jorge : Entrevista a Ricardo Piglia ATENEA: Revista de Ciencia, Arte y Literatura de la Universidad de Concepción Concepción, Chile (Atenea). 1996 Jan-June, 473, 95-109

- Berg, Edgardo-H: La conspiración literaria (sobre La ciudad ausente de Ricardo Piglia) Hispamerica:Revista de Literatura, Gaithersburg, MD (Hispam) 1996 Dec, 25:75, 37-47

- Culler, Jonathan: Dekonstrukció, Osiris Kiadó, Budapest, 1997 (ford.: Módos Magdolna)

- Chandler, Raymond: Cartas y escritos inéditos, Buenos Aires, Editorial La Flor, 1976

- Ferrer, Carolina: Una compleja máquina de narrar: La ciudad ausente de Ricardo Piglia www.uchile.cl/facultades/filosofia...caciones/cyber/Cyber3/textos/CFERRER.HTML

- Fry, Northrop: Az Ige hatalma, Európa Könyvkiadó, Budapest, 1997 (Ford.: Pásztor Péter)

- Gnutzmann, Rita: Ricardo Piglia o la crítica literaria como relato detectivesco Literatura como intertextualidad. IX. Simposio Internacional de Literatura Instituto Literario y Cultural Hispánico, Buenos Aires, 1993, 524-531

- Juan Alcira Arancibia (ed.)

- Harvey, Irene: Derrida and the Economy of Difference Studies in phenomenology and existential philosophy, Bloomington, Indiana University, Pr., cop.1986

- Iglesia, Cristina: Crimen y castigo: Las reglas del juego Notas sobre La ciudad ausente de Ricardo Piglia, Filología, Buenos Aires, Argentina (Filología). 1996, 29:1-2, 95-103

- Lindstrom, Naomi: La historia literaria de los 1920 y 1930 en La ciudad ausente de Ricardo Piglia www.lanic.utexas.edu/project/lasa95/lindstrom.html

- Macchi, Marisa-Fabiana: La máquina de la escritura, Torre de Papel, Iowa City, IA (TdP). 1998 Spring, 8:1, 45-62

- Poe, Edgar Allan: Cuentos 1-2 Prólogo, traducción y notas de Julio Cortázar Alianza Editorial, S. A., Madrid, 1988

- Piglia, Ricardo: Crítica y ficción, Siglo Veinte. Entrevistas. Universidad Nacional del Litoral, Buenos Aires, 1990.

- Piglia, Ricardo: Locos, bandidos y fundamentalistas, Calrín, 9-V-1993

- Piglia, Ricardo: Nombre falso, Siglo Veintiuno Editores S. A., Buenos Aires, 1975

- Piglia, Ricardo: Respiración artificial, Seix Barral/Biblioteca Breve, Buenos Aires, 1996

- Piglia, Ricardo: La ciudad ausente, Espasa-Calpe Argentina S. A./Seix Barral, Buenos Aires, 1995

- Viereck, Roberto: De la tradición a las formas de la experiencia. Entrevista a Ricardo Piglia, RevistaChilena-de-Literatura, Santiago, Chile (RChl). 1992 Nov, 40 


\section{Cselik Ágnes \\ Ricardo Piglia: "La ciudad ausente" címü novellájának narratív struktúrája}

Ricardo Piglia 1940-ben született kortárs argentin szerző. Magyarországon műveit még alig ismerik, de a latin-amerikai kontinensen és Észak-Amerikában rendkívül elismert szerző, sőt az utóbbi időben Spanyolországban is egyre népszerübb íróvá vált. Ricardo Piglia nemcsak regény- és novellaíró, hanem kritikus is. Regényei a következők: Respiración artificial (1980), La ciudad ausente (1992), Plata quemada (1997). Novelláskötetei: La invasión (1967), Nombre falso (1975), Prisión perpetua (1988) és Cuentos morales (1995). Kritikusi, irodalomelméleti munkája a Crítica y ficción (1990) és a Formas breves (2000) címet viseli. Jelen tanulmány egy, a La ciudad ausente címü regény narratológiai szempontból elemző PhD értekezés zárófejezete. A La ciudad ausente Ricardo Piglia legkevesebbet elemzett müvei közé tartozik, hiszen a regény érvénytelennek nyilvánítja a megszokott olvasási, értelmezési, tájékozódási stratégiákat, így mélyebb elemzés nélkül „érthetetlen”, illetve „olvashatatlan”. Ez az összetettség a következő elemekből tevődik össze:

1. A La ciudad ausente című regényben a három fö történetszál mellett több „mikrotörténet” is beleszövődik a mü szövetébe.

2. A konkrét történelmi helyzetet bemutató politikai ábrázoláson túl a La ciudad ausente minden katonai diktatúra azonos működési mechanizmusáról fest képet.

3. A narráció mitikus tevékenység, aminek nincs konkrét ideje. A regényben minden két óra, két nap, két hónap, illetve két év alatt történik.

4. Habár a narráció tere három szintre bontható (város, vidék, sziget), a regényben ábrázolt tér nem konkrét, tere a 'bárhol', ideje a 'bármikor'.

5. A tér és az idő absztrakt jellegével szemben az eltünés és a hiány a La ciudad ausente címü regényben materiális valóság. Nincsenek személyiségek, nincs kommunikáció, nincs barátság, nincs szerelem, nincs család.

6. Megszűnik a reális-fikció ellentét és az alá-/fölérendeltség. A regény tere úgy működik, mint egy prizma, amely a valóság különböző dimenzióit egymás mellé vetítve ábrázolja. Az ok-okozati rendszer szerint müködő logika ebben a világban érvényét veszti.

7. Az egyén (a föszereplő és az olvasó) a regény kezdetén keresésbe fog, valamilyen bizonyosság után kutat. A kezdeti kérdések a regény végén megismétlődnek, nincsenek egyértelmü, megkérdőjelezhetetlen válaszok.

8. A regényben szereplő mesélőgép nem konkrét szerkezetet jelöl, hanem egy metonimikus megfogalmazás arra, ami „tiszta energia”, tehát egy perpetuum mobile. Átvitt értelemben a „gép” nem azt tükrözi, amit lát, hanem azt, amit nem lát, azaz a hiányt.

9. A regény a szó derridai értelmében eltörli a politikai valóságot. Úgy lázad ellene, hogy érvénytelennek nyilvánítja. Az anoním politikai hatalommal szemben absztrakt aktánsok állnak, akiknek nincs más valóságos cselekedetük, mint a narráció.

10. A totális megfigyeltséggel szembeni ellenállást a mü összetettsége biztosítja. A politikai hatalom nem tud behatolni a szövegbe, nem tudja megváltoztatni a narráció kódját és képtelen meghamisítani, manipulálni a jelentést. A regény szövege titkosírással íródott, és ez nem más, mint az absztrakció. 